\title{
EVALUATION OF GROUNDWATER QUALITY AT COCONUT HUSK RETTING AREA
}

\author{
JESSY MOL, I. ${ }^{{ }^{*}}-$ BASKARAN, T. $^{2}$ \\ ${ }^{1}$ Civil Department, St. Xavier's Catholic College of Engineering \\ Nagercoil 629003, Tamil Nadu, India \\ (e-mail: jessymol@gmail.com) \\ ${ }^{2}$ Civil Department, Thiagarajar College of Engineering \\ Madurai 625015, Tamil Nadu, India \\ (e-mail: tbaskaran70@gmail.com) \\ *Corresponding author \\ e-mail: jessymol@gmail.com \\ (Received $9^{\text {th }}$ Mar 2017; accepted $2^{\text {nd }}$ Jun 2017)
}

\begin{abstract}
This paper evaluates the quality of the groundwater in and around a coconut husk retting area. The area selected for the study is Mondaikadu of Kanyakumari district, Tamil Nadu, India, which is very near to the coast of the Indian Ocean. Groundwater samples were collected during summer, winter and pre-monsoon season and analyzed using analytical instruments. It was observed that the groundwater quality is significantly affected by coconut husk retting process. The $\mathrm{pH}$ level in the groundwater was found to be unacceptable because it was below the permissible limit of 6.5 to 9.2 as per the World Health Organization (WHO) and Bureau of Indian Standards (BIS). All other parameters such as Total Dissolved Solids (TDS), Electrical conductivity (EC), Hardness, Calcium (Ca), Magnesium (Mg), Sodium (Na), Potassium $(\mathrm{K})$, Ferrous $(\mathrm{Fe})$, Manganese $(\mathrm{Mn})$, Nitrate $\left(\mathrm{NH}_{3}\right)$, Chloride $(\mathrm{Cl})$, Fluoride $(\mathrm{F})$, Sulphate $\left(\mathrm{SO}_{4}\right)$ are within the limits. Low $\mathrm{pH}$ water was neutralized using addition of Sodium Hydroxide methods $(\mathrm{NaoH})$, addition of soda ash and aeration process. Using correlation analysis, the dependent and independent variables were selected and regression analysis was conducted for these variables and the best fit regression model was created.
\end{abstract}

Keywords: correlation, regression, $\mathrm{pH}$, electrical conductivity, neutralizer

\section{Introduction}

Water is one of the most common and most precious resources of our earth. About $80 \%$ of the earth's surface is covered with water. It cannot be made electronically or hydrologically or by any other means (Brindha and Elango, 2011). It may be classified as groundwater and surface water. Groundwater is the main source for drinking purpose. Groundwater contains less pollution as compared to surface water and does not have suspended solid particles also having less turbidity (Gajendran et al., 2013). The most important environmental issue is groundwater contamination (Oyelami et al., 2013). About $70 \%$ of India's groundwater resource has been contaminated by organic, inorganic and biological pollution (Anitha and Sugirtha, 2013). Most of the contamination occurs on account of mining, land clearance, agriculture, acid precipitation, domestic and industrial waste (Appelo and Dieke, 2005). Population growth and rapid urbanization are one of the reasons for qualitative degradation of groundwater (Abd El-Salam and Abu-Zuid, 2015). The soil influence on the water quality of an area is very important and it can be described as the process controlling the exchange of chemicals between the soil and water (Hesterberg, 1998). The groundwater quality is constantly changing with respect to season and climate. As per WHO, about 
$80 \%$ of all the diseases in human beings is caused by impure water. Recent results indicated that many groundwater quality analyses have been conducted in different areas, such as landfill leachate, limestone aquifer, municipal land fill lagoons, rural settlement, municipal solid waste site etc. (Abd El-Salam and Abu-Zuid, 2015; Jamshidzadeh and Mirbagheri, 2011; Longe and Balogun, 2010; Adekunle et al., 2007; Kurakalva et al., 2016). It is important to identify the source of pollution to avoid future degradation of groundwater quality (Dieng et al., 2017). This is the first study to conduct the groundwater quality analysis near the coconut husk retting area.

In the process of retting of a coconut husk lot of solid waste is produced. This gets mixed up with solids and gradually decomposes. This merges with the soils and the aquifer and pollutes the groundwater system. The effluent generated from the coir industry is acidic, also contains phenolic compounds and other toxic substances (Simple Lotus, 2012). The heavy pollution caused by the retting yards is found to have serious environmental degradation and ecosystem damage. Many researchers analysed the physic- chemical characters of the retting water and finally they found that it will affect the retting water and land. It causes serious health impacts to the people (Najee and Philipose, 2013; Manoj, 2014). Due to the contamination of surface water the soil may get contaminated (MaryHelen et al., 2011). This leads to groundwater contamination. In order to assess the quality of water continuously, prediction is needed. The prediction can be used for resource planning and management if it is of acceptable accuracy (Seyyed et al., 2013). Recently, mathematical, statistical, computational and spatial analysis is used to simulate and assess many aquifer water quality parameters. Spatial analysis of pollution is used to identify the source of the pollution in a particular study area (Ang et al., 2016).

Regression analysis was the linear modelling tool used for prediction. It is a form of predictive modelling technique which investigates the relationship between a dependent and independent variable. This technique was used for forecasting, time series modelling and finding the causal effect relationship between the variables. The curve must be fitted to the data points, in such a manner that the differences between the distances of data points from the curve or line was minimized. In this study it was used to predict one dependent variable by using other independent variables.

The main aim of this study is to assess the groundwater contamination in the area specified, to compare the water quality parameters with drinking water quality standards, suggestions were given to treat the contaminated water and the groundwater quality modelling is created. Regression analysis is used to create the groundwater models. The parameters selected for analysis were based on the correlation matrices.

Kanyakumari District is mostly covered by costal area. The geographical extent of Kanyakumari District is $1,672 \mathrm{~km}^{2}$. The soil type is mostly red loam and laterite with coastal alluvium in the south. The district has a warm and humid climate with a maximum day temperature ranging between $24{ }^{\circ} \mathrm{C}$ and $34{ }^{\circ} \mathrm{C}$ throughout the year and an annual rainfall of $146 \mathrm{~cm}$. The main occupations of the coastal area are coir making and fishing (ENVIS Centre, Tamil Nadu). In the coir production process, the coconut husk is soaked in a retting pond for a period of 6 months to one year. During this period, it may produce a lot of organic, inorganic and biological components. This process is highly affecting the quality of water in the retting pond. It produces a bad smell around the surrounding places.

The area taken for this study is Mondaikadu at Kanyakumari District. Mondaikadu lies between $8^{\circ} 9^{\prime} 47^{\prime \prime}$ latitude and $77^{\circ} 16^{\prime} 48.09^{\prime}$ " longitude. It is a Panchayat town of 
Kanyakumari District, Tamil Nadu. Here, the coconut husk retting operation is carried out near the AVM canal. That canal water is used for the coconut husk retting process.

\section{Material and methods}

The water sampling process was done during winter, summer and monsoon seasons for the period of three years from December 2012 to November 2015. There were 10 groundwater samples collected from different bore wells near the retting site. The specifications of the different bore wells are mentioned in Table 1. Samples were collected in one litre polythene bottles, which were pre cleaned with concentrated hydrochloric acid and distilled water. $\mathrm{pH}$ was measured on the site with a digital $\mathrm{pH}$ meter (Ahamefula et al., 2013). This was done to avoid unpredictable changes in characteristics as per the standard procedure (APHA, 1998). All the collected samples were preserved in the refrigerator and the analysis such as TDS, EC, Hardness, $\mathrm{Ca}, \mathrm{Mg}$, $\mathrm{Na}, \mathrm{K}, \mathrm{Fe}, \mathrm{Mn}, \mathrm{NH} 3, \mathrm{Cl}, \mathrm{F}, \mathrm{SO}_{4}$ were completed in the Environmental engineering laboratory within two days.

Table 1. Specifications of bore wells

\begin{tabular}{c|c|c|c}
\hline Sample no. & Latitude & Longitude & $\begin{array}{c}\text { Elevation } \\
(\mathbf{m})\end{array}$ \\
\hline S1 & $8^{\circ} 9.678^{\prime} \mathrm{N}$ & $77^{\circ} 16.724^{\prime} \mathrm{E}$ & 49.3 \\
$\mathrm{~S} 2$ & $8^{\circ} 9.7^{\prime} \mathrm{N}$ & $77^{\circ} 16.729^{\prime} \mathrm{E}$ & 64.8 \\
$\mathrm{~S} 3$ & $8^{\circ} 9.665^{\prime} \mathrm{N}$ & $77^{\circ} 16.753^{\prime} \mathrm{E}$ & 37.2 \\
$\mathrm{~S} 4$ & $8^{\circ} 9.650^{\prime} \mathrm{N}$ & $77^{\circ} 16.755^{\prime} \mathrm{E}$ & 45.6 \\
$\mathrm{~S} 5$ & $8^{\circ} 9.617^{\prime} \mathrm{N}$ & $77^{\circ} 16.866^{\prime} \mathrm{E}$ & 78.2 \\
$\mathrm{~S} 6$ & $8^{\circ} 9.642^{\prime} \mathrm{N}$ & $77^{\circ} 16.954^{\prime} \mathrm{E}$ & 34.4 \\
$\mathrm{~S} 7$ & $8^{\circ} 9.579^{\prime} \mathrm{N}$ & $77^{\circ} 16.071^{\prime} \mathrm{E}$ & 51.7 \\
S8 & $8^{\circ} 9.571^{\prime} \mathrm{N}$ & $77^{\circ} 16.086^{\prime} \mathrm{E}$ & 50.4 \\
S9 & $8^{\circ} 9.589^{\prime} \mathrm{N}$ & $77^{\circ} 16.032^{\prime} \mathrm{E}$ & 86.1 \\
S10 & $8^{\circ} 9.607^{\prime} \mathrm{N}$ & $77^{\circ} 16.027^{\prime} \mathrm{E}$ & 54.7 \\
\hline
\end{tabular}

\section{Results and discussion}

\section{Statistical analysis}

Physical and chemical properties of the groundwater in all the three seasons are evaluated. Each season has different range of parameters. In general, the winter season has higher values compared to the other two seasons. As compared to WHO (1993) and BIS (2009) standards all parameters are within the permissible limit, except $\mathrm{pH}$. Table 2 shows the comparison of BIS, WHO standards and minimum, maximum range of each parameter. 
Table 2. Statistics $f$ the hydrogeochemical properties with WHO and BIS standard for winter season

\begin{tabular}{c|c|c|c|c|c|c|c|c}
\hline \multirow{2}{*}{ Parameter } & \multicolumn{2}{|c|}{ Winter season } & \multicolumn{2}{c|}{$\begin{array}{c}\text { Summer } \\
\text { season }\end{array}$} & \multicolumn{2}{c|}{$\begin{array}{c}\text { Monsoon } \\
\text { season }\end{array}$} & $\begin{array}{c}\text { BIS } \\
\text { standard }\end{array}$ & $\begin{array}{c}\text { WHO } \\
\text { standard }\end{array}$ \\
\cline { 2 - 7 } & Min. & Max. & Min. & Max. & Min. & Max. & \\
\hline Turbidity & 0 & 1 & 0 & 1 & 0 & 2 & $1-5$ & 5 \\
TDS & 68 & 290 & 60 & 216 & 61 & 383 & $200-500$ & 1000 \\
$\mathrm{EC}$ & 103 & 439 & 98 & 210 & 93 & 580 & $700-3000$ & - \\
$\mathrm{pH}$ & 4.4 & 6.4 & 5.2 & 6.2 & 4.61 & 6.03 & $6.5-8.5$ & $6.5-8.5$ \\
$\mathrm{Hardness}$ & 30 & 100 & 18 & 56 & 26 & 164 & $300-600$ & 500 \\
$\mathrm{Ca}$ & 8 & 26 & 6 & 21 & 7 & 16 & $75-200$ & $75-200$ \\
$\mathrm{Mg}$ & 2 & 10 & 1 & 4 & 2 & 15 & $30-100$ & $50-150$ \\
$\mathrm{Na}$ & 8 & 46 & 6 & 32 & 9 & 44 & - & 200 \\
$\mathrm{~K}$ & 1 & 11 & 1 & 9 & 1 & 7 & - & 12 \\
$\mathrm{Fe}$ & 0 & 0.12 & 0 & 0 & 0 & 0 & 0.3 & 0.3 \\
$\mathrm{Mn}$ & 0 & 0 & 0 & 0 & 0 & 0 & $0.1-0.3$ & 0.1 \\
$\mathrm{NH}_{3}$ & 0 & 0.08 & 0 & 0.46 & 0 & 1 & 0.5 & 1.5 \\
$\mathrm{Cl}$ & 20 & 96 & 20 & 86 & 20 & 164 & $250-1000$ & 250 \\
$\mathrm{~F}$ & 0 & 0.2 & 0 & 0.2 & 0 & 0 & $1-1.5$ & 1.5 \\
$\mathrm{SO}_{4}$ & 3 & 17 & 3 & 17 & 3 & 16 & $200-400$ & 250 \\
\hline
\end{tabular}

\section{pH value}

The $\mathrm{pH}$ range of groundwater for all the three seasons is below the permissible level of WHO and BIS, which means the water is acidic and corrosive in nature. Figure. 1 shows the spatial variation of the $\mathrm{pH}$ in various sampling sites for three seasons. The map was interpolated by using kriging method. Kriging is a linear interpolation procedure that provides linear unbiased estimation for quantities, which vary in space and it is an advanced geostatistical procedure for interpolation (Gunarathna, 2016).

The main reason for low $\mathrm{pH}$ is a low concentration of ions present in the groundwater. The effluent from the retting site is acidic, this may be the reason for low $\mathrm{pH}$ in the study area. As per WHO, if the $\mathrm{pH}$ range is less than 6.5 or greater than 9.2 it affects the portability of the drinking water. But it has no direct impact on human health (Jasem et al., 2010). U.S. environmental protection agency says that low $\mathrm{pH}$ in water can damage the metal pipe and give the sour taste (EPA, 2003). It may be treated by adding neutralizer to the water. Neutralizer prevents the water from reacting with the metal pipe. 


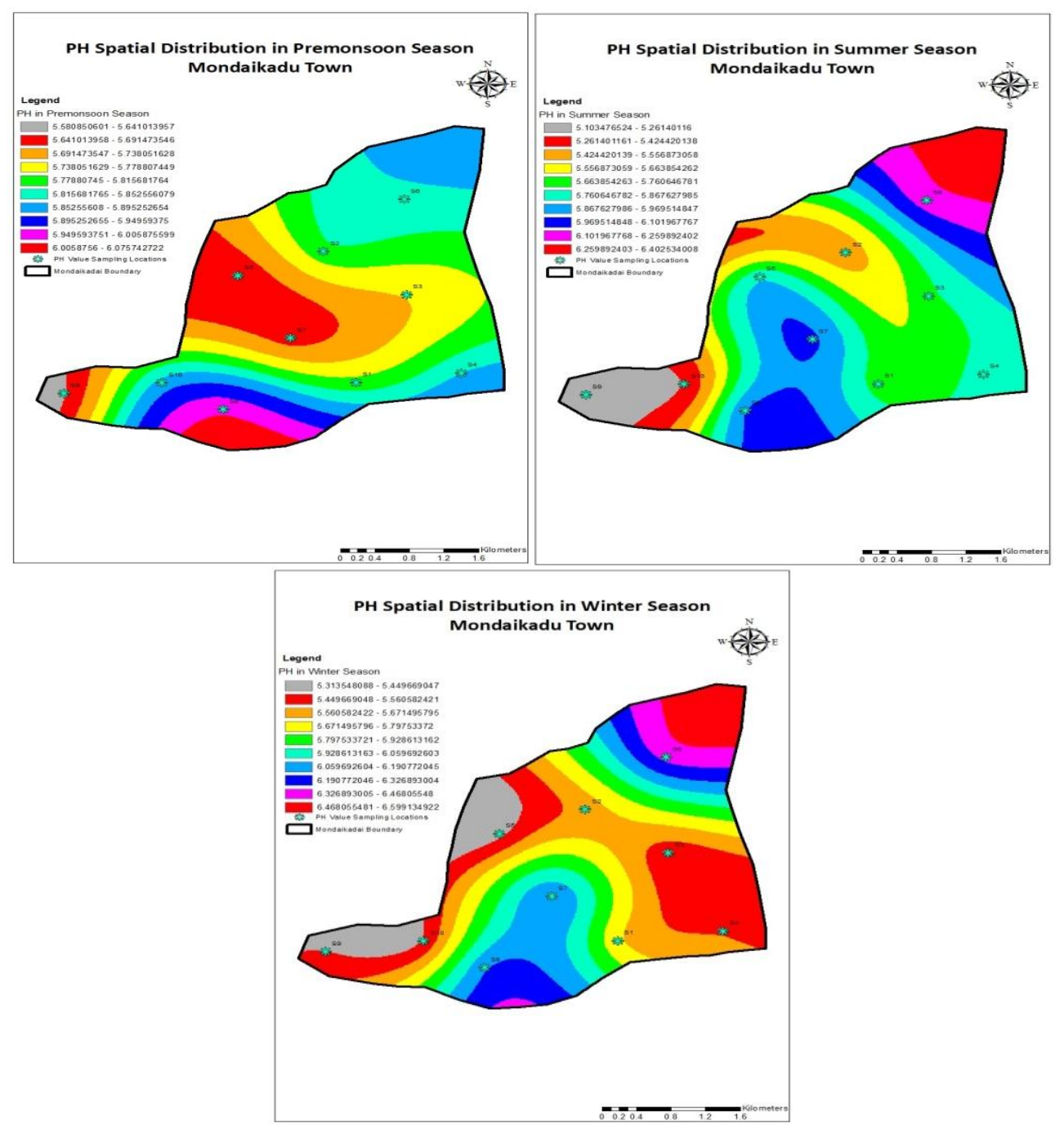

Figure 1. Spatial variation of $\mathrm{pH}$ for three seasons

\section{Neutralize the low $\mathrm{pH}$ water}

\section{Addition of sodium hydroxide $(\mathrm{NaOH})$}

This is the one of the best methods to increase the $\mathrm{pH}$ level in water. Titration method is used to determine the amount of $\mathrm{NaOH}$ needed to raise the $\mathrm{pH}$ of the water. $\mathrm{NaOH}$ solution is prepared by adding $4 \mathrm{~g}$ of $\mathrm{NaOH}$ pellets to $100 \mathrm{ml}$ of distilled water. Then the $\mathrm{NaOH}$ solution obtained is taken as the burette solution and titrated against 20 $\mathrm{ml}$ of water sample. Phenolphthalein $\left(\mathrm{C}_{20} \mathrm{H}_{14} \mathrm{O}_{4}\right)$ is added as the indicator and the end point is colourless to pink. The burette reading gives the amount of $\mathrm{NaOH}$ used for $20 \mathrm{ml}$ of the water sample. If sodium hydroxide is added manually, good ventilation should be maintained to avoid breathing vapours and wear protective gloves, goggles to avoid skin and eye contact (Wagenet et al., 1995).

The amount of $\mathrm{NaOH}$ added to the water is calculated using the below formula:

$$
\mathrm{NaOH} \text { needed }=\frac{(\mathrm{NaOH} \text { used per litre of Sample } \times \text { Normality of } \mathrm{NaOH} \times \text { Equivalent weight of } 1 \text { litre of } 1 \mathrm{~N} \mathrm{NaOH})}{1000}
$$


The calculated quantity of $\mathrm{NaOH}$ added to the water $\left(\mathrm{H}_{2} \mathrm{O}\right)$ and mixed thoroughly suddenly $\mathrm{pH}$ level is increased by the following reaction:

$$
\mathrm{H}_{2} \mathrm{O}+\mathrm{NaOH} \rightarrow \text { aqueous solution containing } \mathrm{NaOH}
$$

Water reacts with $\mathrm{NaOH}$ to form an aqueous solution containing $\mathrm{NaOH}$.

\section{Addition of soda ash}

$120 \mathrm{~g}$ of soda ash is added to $1 \mathrm{~L}$ of water (Glenda and Jennings, 1996). The sample is stirred well, so that the soda ash gets completely dissolved in water. Now the $\mathrm{pH}$ of the water sample is measured. The reaction is taking place as follows:

$$
\begin{gathered}
2 \mathrm{H}_{2} \mathrm{O}+\mathrm{Na}_{2} \mathrm{CO}_{3} \rightarrow 2 \mathrm{NaOH}+\mathrm{H}_{2} \mathrm{CO}_{3} \\
\mathrm{H}_{2} \mathrm{CO}_{3} \rightarrow \mathrm{H}_{2} \mathrm{O}+\mathrm{CO}_{2} \uparrow
\end{gathered}
$$

Water reacts with sodium carbonate $\left(\mathrm{Na}_{2} \mathrm{CO}_{3}\right)$ to form $\mathrm{NaOH}$ and carbonic acid. Carbonic acid decomposes to water and carbon dioxide.

\section{Aeration process}

The process by which air is circulated through, mixed with or dissolved in a liquid is called aeration. In this method, water is taken in a vessel and air is supplied to the water using an aerator. Immediately air bubbles will be produced and the $\mathrm{pH}$ gets increased. Water displacement from the expulsion of bubbles can cause a mixing action to occur and the contact between water and the bubble will result in oxygen transfer. $3.78 \mathrm{~L}$ of water are aerated for $2 \mathrm{~s}$ to increase the $\mathrm{pH}$ of water to a permissible level (Kirby et al., 2007).

Table 3 shows the amount of $\mathrm{pH}$ present in the water before and after the neutralizing process. It seems that all methods of a neutralizer are very effective one.

Table 3. pH before and after neutralizing

\begin{tabular}{c|c|c|c|c}
\hline \multirow{2}{*}{ Sample no. } & \multicolumn{4}{|c}{ Neutralizing method } \\
\cline { 2 - 5 } & Initial & NaOH & Soda ash & Aeration \\
\hline 1 & 5.98 & 7.95 & 7.69 & 8.14 \\
2 & 5.81 & 6.83 & 8.05 & 7.86 \\
3 & 4.67 & 8.07 & 7.70 & 7.74 \\
4 & 5.26 & 7.66 & 6.99 & 7.17 \\
5 & 5.32 & 7.48 & 8.22 & 8.32 \\
6 & 4.74 & 7.52 & 8.12 & 7.58 \\
7 & 4.33 & 6.98 & 6.89 & 7.71 \\
8 & 4.60 & 7.31 & 6.91 & 7.35 \\
9 & 4.4 & 7.1 & 6.7 & 7.12 \\
10 & 4.61 & 7.3 & 6.86 & 7.31 \\
\hline
\end{tabular}




\section{Correlation analysis}

Correlation analysis is used to check the relation between the variables. It is the one of the methods of multivariate statistical study. Many statistical analysis were conducted to determine the temporal variations of the study area. Many statistical analysis were conducted in various research (Özdemir, 2016; Asfandyar et al., 2016; Tokatli, 2015). Correlation analysis is the easiest one among all.

All variables are used to check the correlation. The correlation coefficients are computed using the following equation (Eq.1):

$$
r=\frac{\sum x y}{\sqrt{\left(\sum x^{2} \mathrm{X} \sum y^{2}\right)}}
$$

where $\mathrm{x}=\mathrm{X}-\overline{\mathrm{X}} ; \mathrm{x}=\frac{\sum \mathrm{x}}{\mathrm{n}} ; \quad \mathrm{y}=\mathrm{Y}-\overline{\mathrm{Y}} ; \mathrm{y}=\frac{\sum \mathrm{Y}}{\mathrm{n}} ; \quad \mathrm{n}=$ no of samples.

SPSS 20 software was used to conduct the correlation analysis. There were 50 samples used to find out the correlation between the variables. If the correlation coefficient $(\mathrm{R})$ between the parameters are closer to 1 then the parameters are more positively correlated.

Table 4 shows the correlation matrix for the different variables. It shows that the correlation between fluoride $(\mathrm{F})$ and $\mathrm{Cl}$ is having lower $\mathrm{R}$ value, that is 0.001 .

Table 4. Correlation matrix between the variables

\begin{tabular}{c|c|c|c|c|c|c|c|c|c|c|c}
\hline Parameter & Turbidity & TDS & EC & $\mathbf{p H}$ & Alkalinity & Hardness & Ca & Mg & Na & K & Cl \\
\hline Turbidity & 1 & & & & & & & & & & \\
DS & 0.482 & 1 & & & & & & & & & \\
EC & 0.47 & 0.984 & 1 & & & & & & & & \\
pH & 0.085 & -0.321 & -0.277 & 1 & & & & & & & \\
Alkalinity & 0.355 & 0.7 & 0.708 & -0.253 & 1 & & & & & & \\
Hardness & 0.501 & 0.926 & 0.951 & -0.184 & 0.633 & 1 & & & & & \\
Ca & 0.291 & 0.734 & 0.706 & -0.14 & 0.618 & 0.665 & 1 & & & & \\
Mg & 0.464 & 0.882 & 0.909 & -0.33 & 0.605 & 0.932 & 0.519 & 1 & & & \\
$\mathrm{Na}$ & 0.382 & 0.951 & 0.937 & -0.319 & 0.715 & 0.817 & 0.779 & 0.772 & 1 & & \\
$\mathrm{~K}$ & 0.24 & 0.699 & 0.637 & -0.344 & 0.612 & 0.447 & 0.665 & 0.422 & 0.803 & 1 & \\
$\mathrm{Cl}$ & 0.469 & 0.97 & 0.946 & -0.28 & 0.557 & 0.923 & 0.667 & 0.861 & 0.889 & 0.607 & 1 \\
\hline
\end{tabular}

The reason for the low correlation is due to the ionic alteration by anthropogenic activities (Bodrud-Doza et. al., 2016). EC is highly correlated with TDS, hardness, Mg, $\mathrm{Na}, \mathrm{Cl}$, and the values of correlation coefficient $(\mathrm{R})$ are given in the Table 5. The reason 
for the high correlation was that the parameters are related to each other. If the EC was highly correlated parameter it means it depends on TDS, hardness, $\mathrm{Mg}, \mathrm{Na}, \mathrm{Cl}$. If, these values increase it means EC also increases and if these values reduce that means EC value reduces. Therefore EC was called a dependent variable and other parameters are independent variables. These independent variables are not dependent on EC. These highly correlated variables were used as data for regression analysis.

Table 5. Correlation coefficient $(R)$ value of most correlated parameters

\begin{tabular}{c|c}
\hline Parameters & R value \\
\hline EC-TDS & 0.984 \\
EC-Hardness & 0.951 \\
EC-Mg & 0.909 \\
EC-Na & 0.937 \\
EC- Cl & 0.946 \\
\hline
\end{tabular}

\section{Regression model}

The aim of the regression analysis is to determine the relation between the dependent variable and independent variable. The dependent variable is EC and the independent variables are TDS, Hardness, $\mathrm{Mg}, \mathrm{Na}$, and $\mathrm{Cl}$ are selected from the correlation analysis. Since the number of independent variables is more therefore multiple linear equation is created. Eq. 2 shows the multiple linear equation of the variable:

$$
y=a_{1} x_{1}+a_{2} x_{2}+a_{3} x_{3}+a_{4} x_{4}+a_{5} x_{5}+c
$$

where $y$ represents the EC content and, $x_{1}, x_{2}, x_{3}, x_{4}, x_{5}$, represent the TDS, Hardness, $\mathrm{Mg}, \mathrm{Na}, \mathrm{Cl}$ respectively; $a_{1}, a_{2}, a_{3}, a_{4}, a_{5}$ are the corresponding coefficient of the independent variables, $c$ is the constant of the regression equation. The best fit model is found based on the coefficient of determination $\left(\mathrm{R}^{2}\right)$. If it is nearer to 1 , there is a good relationship between the dependent and independent variables.

Multiple linear regression analysis were conducted in the Matlab programming for the regression model. The constants are calculated and the model is developed as Eq. 3:

$$
y=0.0129 x_{1}-0.141 x_{2}+0.112 x_{3}+6.46 x_{4}+1.64 x_{5}+131.66
$$

Figure 2 shows the regression plot for the target and predicted EC content. The $\mathrm{R}$ value of the regression model is 0.95995. It shows that there is a good relationship between the target and the output of the model. Figure 3 shows the linear relationship between the observed and regression predicted EC. The coefficient of determination, $\mathrm{R}^{2}$ value is 0.9215 ; this value shows that the predicted EC has a good coefficient of determination with observed EC. 


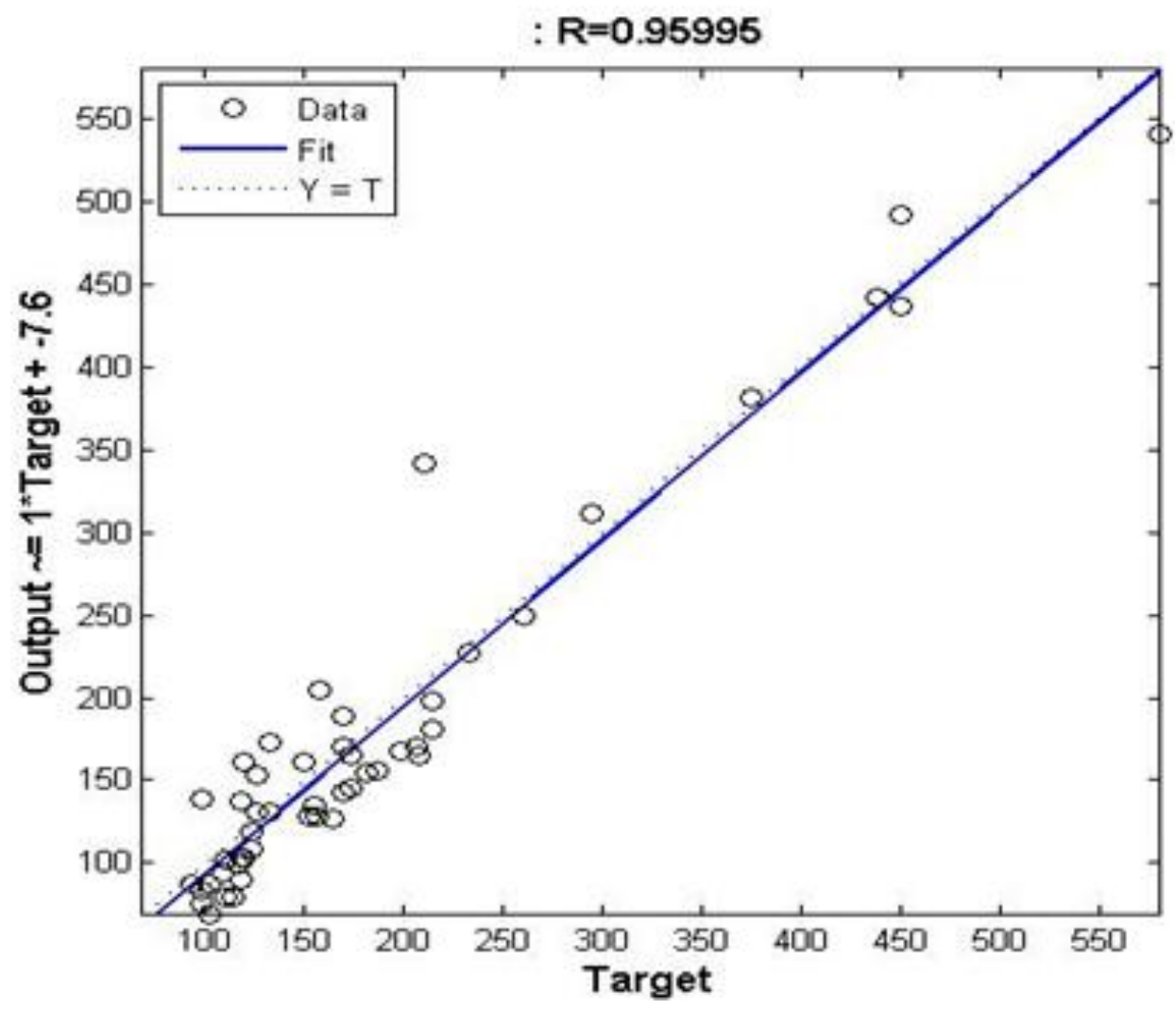

Figure 2. Regression curve for input and target

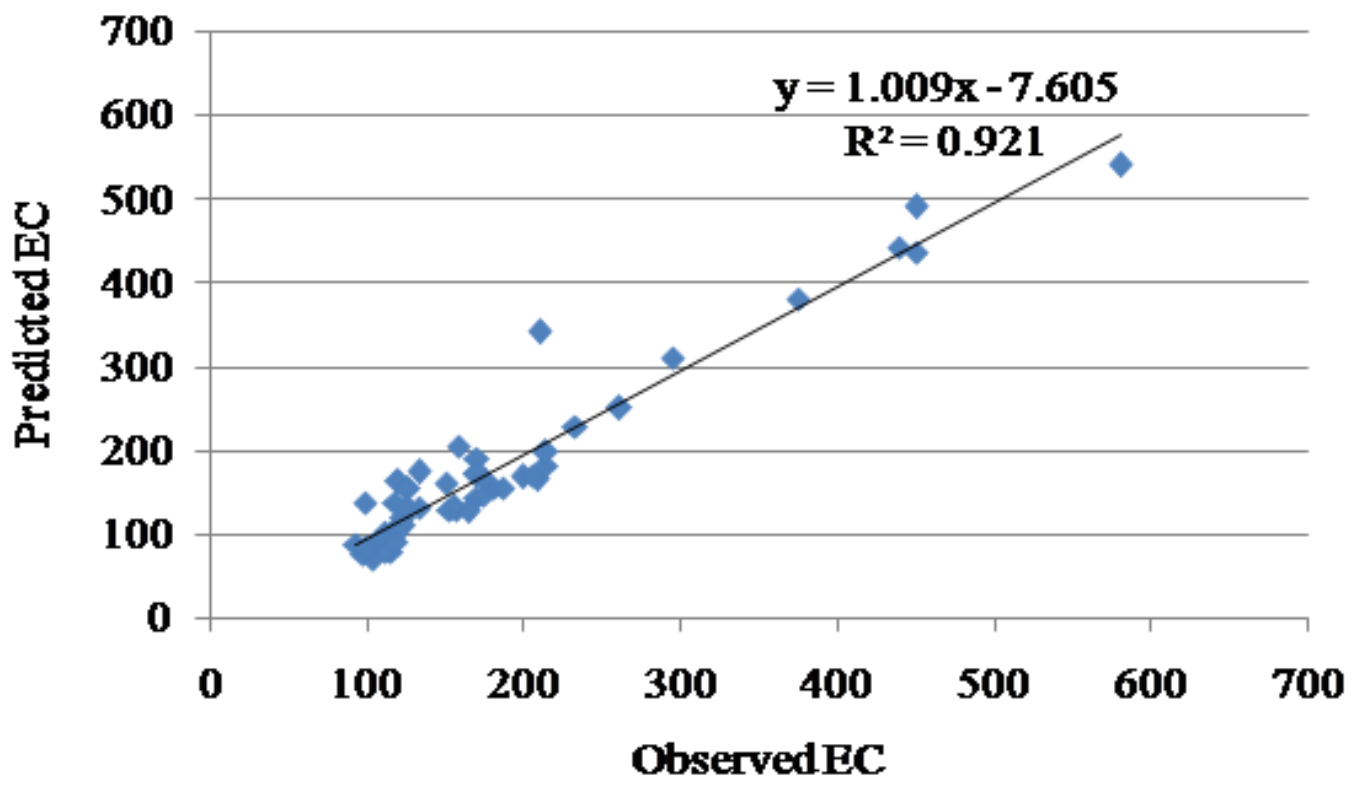

Figure 3. Linear relation between observed and predicted EC

From Figure 4 it is clear that the observed EC was closer to predicted EC. 


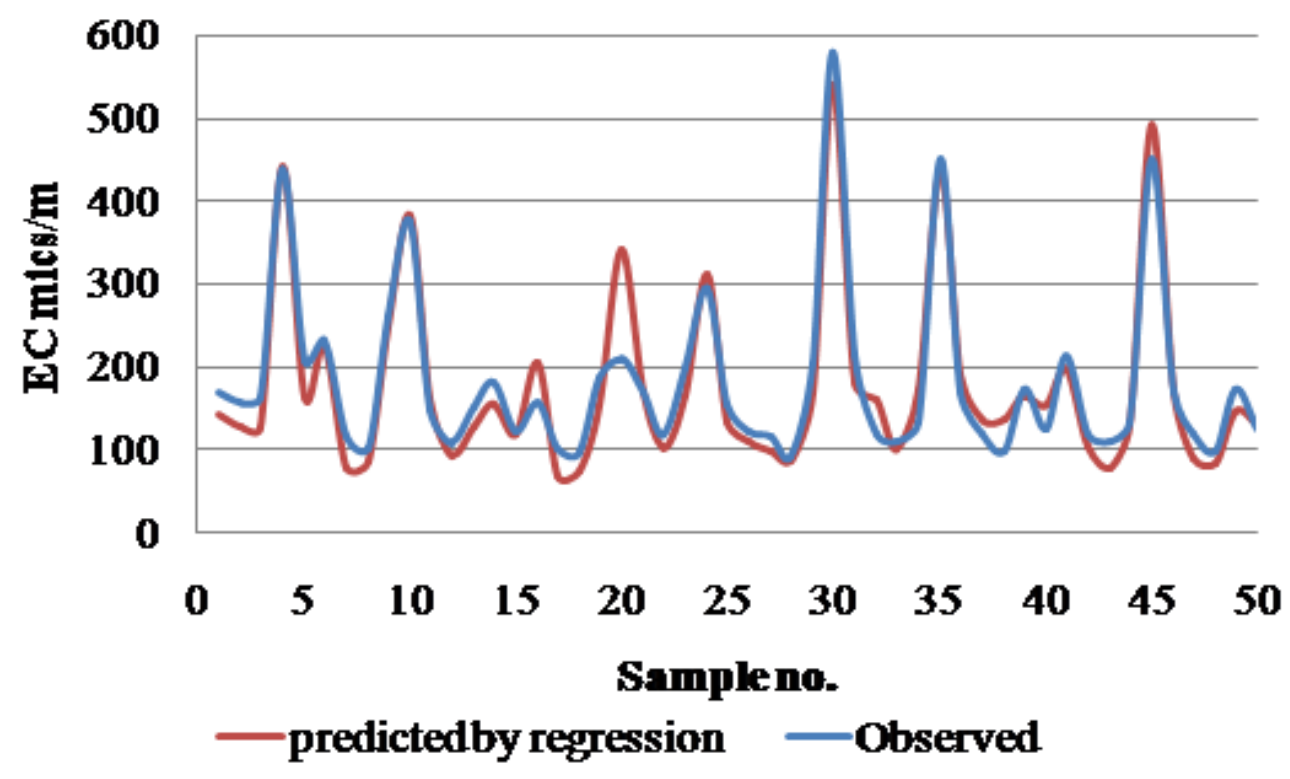

Figure 4. Comparison of observed and predicted EC

\section{Conclusions}

The result of study indicates that the borewell water in the coconut husk retting area are suitable for domestic purpose. The experimental analysis reveals that the parameters such as TDS, EC, Hardness, $\mathrm{Ca}, \mathrm{Mg}, \mathrm{Na}, \mathrm{K}, \mathrm{Fe}, \mathrm{Mn}, \mathrm{NH}_{3}, \mathrm{Cl}, \mathrm{F}$ and $\mathrm{SO}_{4}$ of all 50 samples are within the prescribed limit of WHO and BIS, except for $\mathrm{pH}$. The water can be used for drinking after neutralising by addition of $\mathrm{NaOH}$, addition of soda ash and aeration methods.

The results of correlation analysis shows that EC was highly correlated with other parameters. The regression analysis shows the coefficient of determination for the observed and predicted EC was 0.9215, which was close to one, therefore regression model was a good prediction tool for this problem.

Acknowledgements. I would like to acknowledge my relatives, friends and colleagues for their valuable suggestions and encouragement for preparing this manuscript. I also like to appreciate the reviewers and editors for their suggestions and comments.

\section{REFERENCES}

[1] Abd El-Salam, M. M., Abu-Zuid, G. I. (2015): Impact of landfill leachate on the groundwater quality: A case study in Egypt. - Journal of Advanced Research 6(4): 579586.

[2] Adekunle, I. M., Adetunji, M. T., Gbadebo, A. M., Banjoko, O. B. (2007): Assessment of groundwater quality in a typical rural settlement in Southwest Nigeria. - International Journal of Environmental Research and Public Health 4(4): 307-318.

[3] Ahamefula, U., Benard, I., Egboka, B. C. E., (2013): Assessment of hydrogeochemical characteristics of groundwater quality in the vicinity of Okpara coal and Obwetti fireclay mines, near Enugu town Nigeria. - Applied Water Science (3): 271-283. 
[4] Ang, K. H., Faradiella, M. K., Sarva, M. P. (2016): Spatial variation assessment of river water quality using environmetric techniques. - Polish Journal of Environmental Study 25(6): 2411-2421.

[5] Anitha, G., Sugirtha, P. K. (2013): Seasonal variations in Physico-Chemical parameters of Thengapattanam estuary, South west coastal zone, Tamilnadu, India. - International Journal of Environmental Science 3(4): 1253-1262.

[6] APHA (1998). Standard Methods for the Examination of Water and Wastewater, 20th ed., pp. 2005-2605. - American Public Health Association, Washington, DC.

[7] Appelo, C. A. J., Dieke, P. (2005): Geochemistry, Groundwater and Pollution. - A.A. Balkema Publishers, Amsterdam.

[8] Asfandyar, S., Qi, S., Audil, R., Faizan, U. H., Muhammad, T. S. (2016): Evaluation of water quality for drinking and agricultural suitability in the Lower Indus Plain in Sindh Province, Pakistan. - Polish Journal of Environmental Study 25(6): 2563-2574.

[9] BIS (2009). Indian Standards Specifications for Drinking Water, IS:10500. - Bureau of Indian Standards, New Delhi.

[10] Bodrud-Doza, M. D., Towfiqul, A. R. M., Fahad, A., Samiran, D., Narottam, S., Safiur, M. (2016): Characterization of groundwater quality using water evaluation indices, multivariate statistics and geostatistics in central Bangladesh. - Water Science 30: 19-40.

[11] Bouri, S. (2017): A global risk approach to assessing groundwater vulnerability. Environment Modelling and Software 88:168-182.

[12] Brindha, K., Elango, L. (2011): Hydrochemical characteristics of groundwater for domestic and irrigation purposes in Madhuranthakam, TamilNadu, India. - Earth Sciences Research Journal 15(2): 101-108.

[13] Dieng, N. M., Orban, P., Otten, J., Stumpp, C., Faye, S., Dassargues, A. (2017): Temporal changes in groundwater quality of the Saloum coastal aquifer. - Journal of Hydrology: Regional Studies 9:163-182.

[14] ENVIS Centre, Tamil Nadu. tnenvis.nic.in/files/KANYAKUMARI\%20\%20.

[15] EPA Report (2003). pH Values of Water Explained. - U.S. Environmental Protection Agency - Advanced Purification Engineering Research Triangle Park, N. C., USA.

[16] Gajendran, C., Jayapriya, S., Diana, Y., Oshin, V., Christina, J. (2013): Assessment of groundwater quality in Tirunelveli District, Tamil Nadu, India. - International Journal of Environmental Science 3(6): 1847-1880.

[17] Glenda, M. H., Gregory, D. J., (1996): Home Drinking Water Treatment Systems. North Carolina Cooperative Extension Service.

[18] Gunarathna, M. H. J. P., Kumari, M. K. N., Nirmanee, K. G. S. (2016): Evaluation of interpolation methods for mapping $\mathrm{pH}$ of groundwater. IJLTEMAS 5(3): 1-5.

[19] Hesterberg, D. (1998): Biogeochemical cycles and processes leading to changes in mobility of chemicals in soils. - Agriculture, Ecosystems \& Environment 67(2): 121-133.

[20] Jamshidzadeh, Z., Mirbagheri, S. A. (2011): Evaluation of groundwater quantity and quality in the Kashan Basin, Central Iran. - Desalination 270(1-3): 23-30.

[21] Jasem, M., Fawzia, M., Zaid, M. (2010): Groundwater quality analysis of limestone aquifer of Al-Sulaibiya field Kuwait. - Desalination 254: 58-67.

[22] Kirby, C. S., Dennis, A., Kahler, A. (2007): Aeration to degas $\mathrm{CO}_{2}$, increase $\mathrm{pH}$ and iron oxidation rates, and decrease treatment pond size in treatment of net alkaline mine drainage. - Proceedings of the 24th Annual Meeting of the American Society of Mining and Reclamation, June 2-7, 2007, Gillette, Wyoming, pp. 373-381.

[23] Kurakalva, R. M., Aradhi, K. K., Mallela, K. Y., Venkatayogi, S. (2016): Assessment of groundwater quality in and around the Jawaharnagar municipal solid waste dumping site at Greater Hyderabad, Southern India. - Procedia Environmental Science 35: 328-336.

[24] Longe, E. O., Balogun, M. R. (2010): Groundwater quality assessment near a municipal landfill Lagos, Nigeria. - Research Journal of Applied Sciences, Engineering and Technology 2(1):39-44. 
[25] Manoj, K. (2014): Study on environmental degradation by retting activities in back waters of Kodungallur, Thrissur District, Kerala State, South India. - Journal of Environmental Science, Computer Science and Engineering \& Technology 3(1):156-163.

[26] Mary Helen, P. A., Jayasree, S., Antony, J., Belsha, I. H., Chittarasu. (2011): Seasonal variations in physicochemical, parameters of water in coconut, husk retting area, Parakkani, Tamil Nadu. - International Journal of Environmental Science 1(6): 10561061.

[27] Najee, M., Philipose, M. C. (2013): Pollution of Ashtamudi Estuary due to retting of coconut husk and its environmental impacts. - International Journal of Scientific and Engineering Research 4(8). https://www.ijser.org/researchpaper/Pollution-Of-AshtamudiEstuary-Due-To-Retting-Of-Coconut-Husk-And-Its-Environmental-Impacts.pdf

[28] Oyelami, A. C., Aladejana, J. A., Agbede, O. O. (2013): Assessment of the impact of open waste dumpsites on groundwater quality: a case study of the Onibu-Eja dumpsite, southwestern Nigeria. - Procedia Earth and Planetary Science 7: 648-651.

[29] Özdemir, O. (2016): Application of multivariate statistical methods for water quality assessment of Karasu-Sarmisakli Creeks and Kizilirmak River in Kayseri, Turkey. Polish Journal of Environmental Study 25(3): 1149-1160.

[30] Seyyed, A. M., Gholam, A. K., Zeynab, P., Zeynab, B., Mohammad, S. (2013): Estimate the spatial distribution TDS the fusion method Geostatistics and artificial neural networks. - International Journal of Agriculture and Crop Sciences 6 (7): 410-420.

[31] Simple Lotus, C. F. (2012): Physico-chemical variations of different coconut husk ponds. - Journal of Basic and Applied Biology 6(3-4): 114-117.

[32] Tokatli, C. (2015): Assessment of water quality in the Meriç River as an ecosystem element in Turkey's Thrace region. - Polish Journal of Environmental Study 24(5): 22052211.

[33] Wagenet, L., Mancl, K., Sailus, M. (1995): Home Water Treatment. - Northeast Regional Agricultural Engineering Service, Cooperative Extension, NRAES-48, Ithaca, NY.

[34] World Health Organization (2008): Guidelines for drinking water quality. Recommendations Geneva, 1, 1308. 